Volume 3 Issue 9 (June 2021) PP. 50-65 DOI: 10.35631/IJMOE.39005

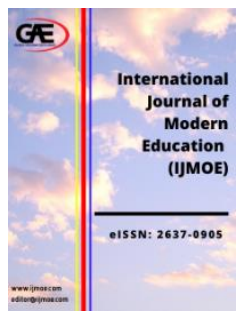

\author{
INTERNATIONAL JOURNAL OF \\ MODERN EDUCATION \\ (IJMOE) \\ WWW.ijmoe.com
}

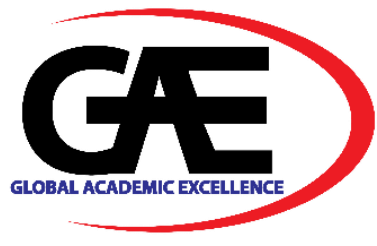

\title{
BOARDING SCHOOL HEALTHY EATING POLICY IMPLEMENTATION OPINIONS OF SCHOOL TEACHERS: A QUALITATIVE STUDY
}

\author{
Zafirah Mohd Nor ${ }^{1 *}$, Abdul Rashid Abdullah², Rosita Jamaluddin ${ }^{3}$, Hazrina Ghazali ${ }^{4}$ \\ 1 School of Health Sciences, Universiti Sains Malaysia (USM), Malaysia. \\ Email: zafirah.mohdnor@usm.my \\ 2 School of Business and Economics, Universiti Putra Malaysia (UPM), Malaysia. \\ Email: rashidabdullah@upm.edu.my \\ 3 Faculty of Medicine and Health Sciences, Universiti Putra Malaysia (UPM), Malaysia. \\ Email: rositaj@upm.edu.my \\ 4 Faculty of Food Science and Technology, Universiti Putra Malaysia (UPM), Malaysia. \\ Email: hazrina@upm.edu.my \\ Corresponding Author
}

\section{Article Info:}

Article history:

Received date: 14.04 .2021

Revised date: 20.04.2021

Accepted date: 31.05 .2021

Published date: 15.06 .2021

\section{To cite this document:}

Nor, Z. M., Abdullah, A. R., Jamaluddin, R., \& Ghazali, H. (2021). Boarding School Healthy Eating Policy Implementation Opinions of School Teachers: A Qualitative Study. International Journal of Modern Education, 3(9), 50-65.

DOI: $10.35631 / \mathrm{IJMOE} .39005$

This work is licensed under $\underline{\text { C BY } 4.0}$

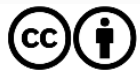

\begin{abstract}
:
The collaboration between the Malaysian education and health ministry introduced a school healthy eating policy, where there was a requirement for food and drinks provided within the boarding schools to conform to standards based on macronutrients and energy content. The aim of the present study was to explore the experience of implementing a school healthy eating policy to inform the compliance of such policies being implemented into practices in the boarding school foodservice setting. A qualitative approach was used, with indepth interviews exploring informants' involvement in, experiences of, factors affecting, and perceived outcomes of policy implementation. Interviews were conducted with fifteen teachers involves in administering the implementation of the school's healthy eating policy. Results were analyzed using a thematic analysis approach. Perceived challenges to implementation of school healthy eating policy included: students' eating preferences, students' eating style, unchanged menu cycle selections, and unhealthy choices of canteen menu. Teachers' recommendations for successful implementation of policy to be well-practiced in real situations included: enhancement in nutritional education, revise menu, create a conducive healthy eating environment and limit the hours to the canteen. Participants identified that successful policy implementation hinged on the provision of resources and support by the government to the school stakeholders. Implementing a healthy eating policy within the boarding school setting benefits from dedicated resourcing, investment in relationship building with various stakeholders, and introducing changes gradually with a long-term approach.
\end{abstract}




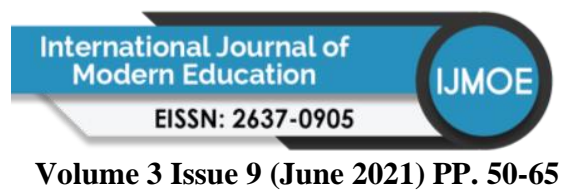

Volume 3 Issue 9 (June 2021) PP. 50-65 DOI: 10.35631/IJMOE.39005

Keywords:

Healthy Eating Policy, Boarding School, Foodservice

\section{Introduction}

Obesity among children and adolescents is a serious public health concern both globally (Bancej et al., 2015; Fryar, Carroll, \& Ogden 2018) and in Malaysia [Ministry of Health $(\mathrm{MOH}), 2016]$. The current statistic from the health ministry report in 2016, indicated that three different age groups of children and adolescents showed an increased rate of more than double from 2011 to 2015 . The prevalence rate of children and adolescent's obesity age 5-9 years old indicated $6.7 \%$ to $14.4 \%$, and adolescents' group age from 10 to 14 years old and 15 to 17 years old showed $6.3 \%$ to $14.4 \%$ and $4.9 \%$ to $9.6 \%$ respectively (MOH, 2016). The growing pattern of overweight and obesity among adolescents in Malaysia has seriously become a challenge to the public health concern whereby this problem is significant determinant factors that can be related to severe chronic diseases in which can continue into adulthood (Llewellyn, Simmonds, Owen, \& Woolacott, 2016; Reinehr, 2018). As these severe chronic diseases progress, the treatment cost of a country will increase and become an economic burden in the future (Helble $\&$ Fransisco, 2017). Once established, obesity is difficult to reverse, thus strengthening the case for primary prevention.

Various stakeholders from the top to down approach are required with the action plan in multiple settings to overcome the obesity issue effectively as suggested by The World Health Organisation (WHO, 2014). Furthermore, nutrition and physical activity are the main component of obesity prevention that can be targeted through well-plan policy interventions implemented in schools setting. Policy intervention is a potential tool to improve healthy eating in schools and more sustainable than programs focused on individual behavior change (Valaitis, 2015). Schools are the right setting that provides opportunities for prevention of under or over nutrition issues, as they provide the best access to a large number of young people group including children and adolescents (Brown \& Summerbell, 2009; Dobbins, Husson, DeCorby, \& LaRocca, 2013). The school was recognized as a critical place to influence healthy eating habits and encourage the children to be active physically because they spend much time of their waking hours at schools. Several school feeding programs were established and have been used as a proper mechanism to address health and education issues such as children's dietary intake, education enrolment, school retention, and food safety and hygiene issues (Buluku, 2012). Through the school meal program, the provision of balanced meals in terms of calorie counts, proper portion sizes, and adequate nutrition components could improve the nutritional status and adoption of health measures for the sustainable provision of adequate quality, quantity, and composition of the meals and snacks provided (FAO, 2019). Thus, the government is responsible developing for policy-led solution nutrition goals and health priorities of the target populations.

Despite previous attempts to increase the healthiness of the school environment across schools in Malaysia, empirical evidence regarding the healthy eating policy implementation has not been adequately investigated. Local studies that have paid attention to feeding issues have only focused on dietary practices (Abdul Aziz \& Devi, 2012; Abdul Majid et al., 2016), nutrition intake (Al-Sadat et al., 2016; Koo et al., 2020; Nutrition Society of Malaysia [NSM], 2015), malnutrition status, school food environment (Hayati Adilin et al., 2015; Rosmawati et al., 


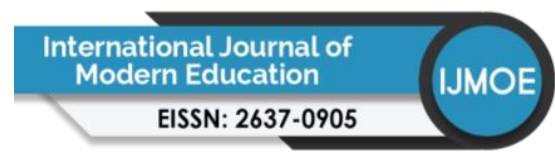

Volume 3 Issue 9 (June 2021) PP. 50-65 DOI: $10.35631 / \mathrm{IJMOE} .39005$

2017), food hygiene and safety (Tan et al., 2015) whiles the extent to which how good the written healthy eating policy can be implemented in the real scenario appears overlooked. Additionally, most of the implementation of the guidelines related to targeted school feeding programs is mainly focusing on day school setting (Khalidi \& Gen, 2020). This is unfortunate because students in boarding high schools are defined as a vulnerable group and should be given equal attention because they rely on meals provided by the school as the main source of all their nutrient needs during their stay. Boarding schools are a major concern as a core of this study because it focuses on a population of adolescents living and eating away from a safe and supportive family environment. Furthermore, boarding schools are considered to the students' second home so that they require great care and attention particularly on their basic life necessities such as dietary eating intake (Mensah \& Appietu, 2019). Thus, the purpose of this study was to assess the critical challenges or barriers in implementing policy into practices from the perspective of school teachers to identify the areas for improvement. Insights from the teachers are very imperative to examine because they have varied valuable input to offer on the policy issues.

\section{Literature Review}

\section{Canteen and Dining Foodservices in Boarding Secondary Schools}

The boarding schools are known as a controlled residential setting in which the students are accommodated to structured education, social, and physical activities throughout the day (Serrem et al., 2020). The boarders are required to stay, eat and sleep in the facilities (Bass, 2014), hence, the provision of meals to the boarders is one of the required services that give much impact on student's health and academic performance (Weaver-Hightower, 2011). Likewise, to most other countries, the school foodservice in Malaysia is categorized as a noncommercial operation and it is an auxiliary service to the provision of education in schools with an allocation limited budget proposed by the government. For public boarding schools in Malaysia, though students have to pay fees for the meals, schools receive government subsidization $(\mathrm{MOH}, 2016)$. The boarders receive their meals which are prepared by the appointed foodservice providers who win the bidding contract and the foodservice providers are responsible to serve the meals at schools' dining halls. The meal provision in boarding schools comprised at least 5 mealtimes per day including breakfast, lunch, tea-time, dinner, and supper, and required all boarders compulsory to participate in having their meals in the dining hall (MOE, 2010). Unlike subsidized boarding school foodservice, other sources of meals which are purchased at the cost of students also available in the school setting such as school canteens/cafeteria, food vendors, and school food store (Ababio, Taylor, Swainson, \& Daramola, 2016). Notably, the availability of non-commercial foodservice particularly in the educational setting has attracted considerable research attention in the context of the welfare category (Maietta \& Gorgitano, 2016; Tan et al., 2015).

\section{School Healthy Eating Policy for Schools' Dining}

In Malaysia, a range of policies has been introduced to improve the nutritional quality of the foods and drinks available in schools. In 2007, the health ministry introduced the school healthy eating policy for boarding schools (MOE, 2007). The school healthy eating policy serves as a guide tool concerning the provision of meals in the dining hall. Food serving size and menu were developed specifically for students' needs at boarding schools under the supervision of the health and education ministry. Food serving size was measured based on Malaysia Nutritional Intake (2005), which is for each student their calorie intake is between 2000-2600 


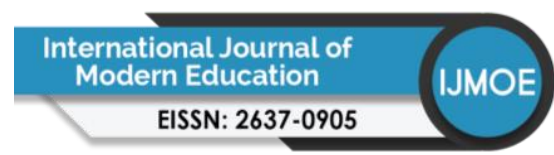

Volume 3 Issue 9 (June 2021) PP. 50-65 DOI: $10.35631 / \mathrm{IJMOE} .39005$

calories. All food items suggested in this menu development are based on suitability, accessibility, and acceptability. The foodservice providers can replace any of the food items with other suitable items according to the agreement with school management authorities. The recommended food serving size is per student. The menu development is based on the Malaysia Food Pyramid, which encourages more fiber intakes such as cereals, fruits, and vegetables. Fruits intake must be consumed in every main mealtime, including breakfast, lunchtime, and dinner. Full cream milk or fresh milk is recommended on this menu. It can be consumed directly or added to tea, coffee, or hot chocolate. The menu plan emphasizes reducing sugar and oil consumption as well.

Research studies have clearly shown a few policies on healthy eating have been examined through the school food environment. The development of policies targeted to improve school environments is proven to be useful to encourage healthy eating practices among the students (Cohen et al., 2019; Hirschman \& Chriqui, 2013; Micha et al., 2018). Even though there is a policy that sets specific nutrition standards for all food served and sold to the students; however, the implementation of the school healthy eating/nutritional policy is still not optimal. Some factors linked to discrepancies in healthy eating policy implementation, which can serve as barriers or enablers, including funding, time, resources, programming support, administrative support (Agron et al., 2010; Sanchez et al., 2014), and cafeteria or canteen choices (Sanchez et al., 2014). Additional factors include support from staff and parent understanding as well as accountability for enforcing healthy eating policy in the school setting (Sanchez et al., 2014). Poor dissemination of healthy eating policy with limited strength and comprehensiveness can also be a barrier (Lucarelli et al., 2015; Schwartz et al., 2012).

Several studies emphasized that government policy fostering healthy eating and physical activity could be a beneficial tool for addressing youth obesity (Cygan, Tribbia, \& Tully, 2019; Snelling et al., 2017). A policy can act as a valuable tool to overcome the health issue, however, potentially the quality of policies to be implemented still unclear on how the policy has resulted in successfully improve nutrition and physical activity environment in most U.S school districts (Schwartz et al., 2012). Previous several studies have documented the substantial variability in the quality of written policies (Hoxie- Setterstrom \& Hoglund, 2011; Sieberg, 2018) Chriqui and colleagues (2011) examined a nationally representative sample of school districts over several years and concluded that while the majority of districts created written policies that addressed the required elements, there was striking variability across policies; many were underdeveloped, fragmented, and lacked sufficient plans for implementation and monitoring. The comprehensiveness of written policies can be effective once it is implemented in the real context of the setting. The relationship between the written policy and its implementation remains ambiguous. Some districts may have an extensive great written policy but have not followed through in actually making the changes in schools. Some may not have put plans in order in writing, but have made substantial changes in practice (Schwartz et al., 2012).

\section{Methods}

\section{Setting and Participants}

School healthy eating policy was mandated to all Malaysian boarding schools across the regions. Since the same policy contents applied to all boarding schools, thus location was not the major concern in this study. However, the Central and Southern Regions were selected because the chosen boarding schools' backgrounds are varied. Five boarding schools were 


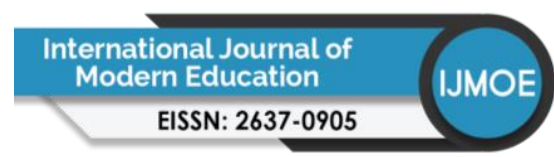

Volume 3 Issue 9 (June 2021) PP. 50-65 DOI: $10.35631 / \mathrm{IJMOE} .39005$

targeted for this study selected from both regions. Three schools are in the city area and two schools are in a rural area. There were two all-female schools, and another three schools were coeducational. Out of five only one school mainly focused on the Islamic stream, and the rest were regular-stream boarding schools.

Five principals and 10 teachers were invited to participate in an in-depth interview from these boarding schools. Principals were recruited because they are responsible supervises all the activities of meal provision at schools such as the meal acceptance, menu, and meal quantity and quality (MOE, 2010a). The best criteria for teachers to be the participants would be those who are on duty as a warden. As a warden, teachers are responsible to assist the hostel/school supervisors to evaluate the quality and quantity of food checklist in boarding schools. Priority was also given to those teachers who teach science, biology, physical education, and civic education to participate in this study because those subjects have minor content to educate students related to healthy eating. Pseudonyms were identified to protect the confidentiality and privacy of all the participants who agreed to have an interview session with a researcher. Those pseudonyms are as follows:

Principals:

$P-A=$ a male principal with 8 years of experience, and a total of 667 students.

$P-B=$ a male principal with 12 years of experience, and a total of 600 students.

$P-C=$ a male principal with 3 years of experience, and a total of 760 students.

$P-D=$ a female principal with 4 years of experience, and a total of 864 students

$P-E=$ a female principal with 10 years of experience, and a total of 732 students.

Teachers:

$T 1-A=$ a male teacher with 8 years of teaching experience, is a chief warden and also assistant of students affairs.

$T 2-A=$ a female teacher with 5 years of teaching experience, teaches biology, and also a warden.

$T 1-B=$ a male teacher with 10 years of teaching experience, is a chief warden, and also assistant principal of student affairs.

$T 2-B=$ a female teacher with 7 years of teaching experience, teaches biology, and also a health coordinator.

$T 1-C=$ a male teacher with 9 years of teaching experience, teaches physical education subjects, and also a warden.

$T 2-C=$ a female teacher with 8 years of teaching experience, teaches biology, and also a warden.

$T 1-D=$ a female teacher with 10 years of teaching experience, teaches history education, is a chief warden, and also assistant principal of student affairs.

$T 2-D=$ a female teacher with 10 years of teaching experience, teaches geography and civic education, and also a warden.

$T 1-E=$ a female teacher with 2 years of teaching experience, teaches science education, and also a warden.

$T 2-E=$ a female teacher with 1 year of teaching experience, teaches civic education, and also a warden. 


\section{Procedure}

An interview protocol was developed including questions to solicit participants' overall experiences and perceptions of the policy, any barriers they experienced, and recommendations to improve the policy implementation. Interviews were semi-structured and based around a topic guide, allowing for flexibility to pursue topics of interest should they arise. The topic guides explored the implementation of the school healthy eating policy using semi-structured questions organized around a review of current relevant literature (Table 1). Participants were contacted via email by the researcher to arrange a convenient time to meet in their respective schools during a regular workday. Interviews were conducted in person which lasted 45 to 60 minutes on average. Interviews were recorded with participant permission. Interview transcripts were de-identified and participants were informed of their rights to confidentiality. Participants were aware of the role and background of the researcher.

Table 1: Open-Ended Questions For Principals And School Teachers In The School District

\begin{tabular}{|ll|}
\hline - & What is your job title (eg., principal, assistant principal, teacher)? \\
\hline - & Tell me about your school background. \\
\hline - & Within your school, would you say healthful eating is a low, medium, or high \\
priority?
\end{tabular}

\section{Data Analysis}

Interview recordings were professionally transcribed. First, categories to organize the data were developed based on the interview question guide, which represented topics of primary interest. Data were funneled into categories following coding. Each of the categories was related to understanding the experiences by participants: barriers, participants' involvement, nutrition activities, menu cycle, and recommendations for policy improvement. The text was coded across multiple categories where appropriate. Emergent coding was used by organizing data within each category into themes. Recurrent codes, or themes, were identified in each of the categories. Differences in coding, though few, were resolved through discussion and the development of consensus among the research committee. 


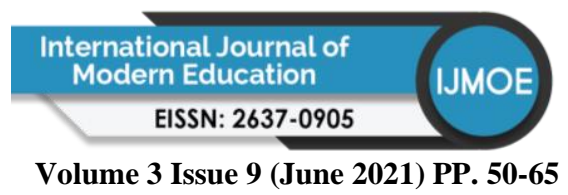

Volume 3 Issue 9 (June 2021) PP. 50-65 DOI: 10.35631/IJMOE.39005

\section{Results and Discussion}

Thematic analysis of the interview data provides a deeper understanding of participants' views, especially in terms of identifying barriers and impediments to the implementation of the policy. A total of 4 major themes emerged. The results presented here reflect the 4 major themes and are supported by verbatim quotations from the participants who were interviewed for this study. Participants were consisting of 6 male and 9 female teachers. All participants were Malay ethnic. The range of working experience among the participants is between 3 to 12 years of working. The total range of students in each boarding school is between 600 to 900 students. The majority of the teachers have teaching experience in subjects such as science, biology, physical education, and civic education. One teacher also holds a position as a school health coordinator. School healthy eating policy for boarding schools included the list of menus explicitly served in the dining hall. The majority of principals agreed that the menus could be considered healthy for their students, but the healthy eating practices in school are still at a moderate rate because students prefer to eat at the canteen than the dining hall. Each participant was asked to describe how well their familiarization and role in promoting healthy eating policy implementation in their school. The participants perceived the policy is relevant to encourage students to eat healthily, however, there is still a challenge to implement it. Participants are also notified that they have no right to make any changes to the policy unless there is a thing to be changed; they are entitled to do so through mutual understandings. Four main themes barriers to healthy eating policy implementation are discussed in detail below.

\section{Students' Eating Preferences}

Participants believed that policy is hard to be carried out if students prefer to eat unhealthy choices. The findings from the point of view of interviewed participants reported that most of the students were less likely to eat vegetables or fruits when being served in the dining hall. The result may be explained by the fact that the lack of fruit and vegetable consumption among the students might be due to taste or the way it is being served to the students. Studies reviewed by Krolner et al., (2011) reported that appearance and taste is the major indicator for students' acceptance towards vegetable consumption. Vegetable preparations are always associated with unpleasant appearances (soggy, bland, unripe, and wrinkled), texture, and taste (bitter, bland, dull, and taste of nothing) (Krolner et al., 2011; Verstraeten et al., 2014). However, vegetable acceptance can be overcome through the right cooking method by adding some appropriate herbs and spices that can boost students' liking towards vegetable palatability (Fritts et al., 2018; Parker et al., 2018). For the consumption of fruits, students prefer cut-fruits rather than the whole one. Not all but most students dislike eating fruits such as apples, oranges, and pears because those fruits are served whole. This has been viewed by a principal $(P-A)$ : "although the menus are balanced, students dislike the food such as certain vegetables and fruits like apples or oranges. They prefer cut fruits but there are certain fruits we can't serve in cut..for example, if we have to serve one apple so we need to serve as one whole based on the menu specification." Students prefer to eat cut fruits more because it is easier for them to eat. Similar to previous research related to fruit consumption, children choose to eat sliced fruits rather than whole fresh fruit because it is tidier, easier to eat, and more appealing to them (Beets et al., 2014; Wansink, Just, Hanks, \& Smith, 2013). Several studies showed that whole fruits contributed to the high number of fruit waste and cut fruit selections are highly consumed by the students (Gase, McCarthy, Robles, \& Kuo, 2014; Handforth, Gilboy, Harris, \& Melia, 2016). It is also notable that students enjoy choosing fruit cups that offered several fruit selections, and it is proven that they are much likely to consume those (Schwartz et al., 2015). 


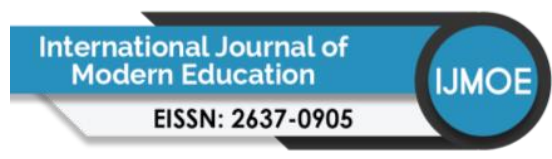

Volume 3 Issue 9 (June 2021) PP. 50-65 DOI: $10.35631 / \mathrm{IJMOE} .39005$

As a result, fruit consumption increases, and waste can be decreased among the students (Schwartz et al., 2015; Wansink et al., 2013).

Interestingly, in this study any cooking styles (fried, gravies or soup) that consist of chickensbased are the most favorite food preferred by most students as compared to any other food group options (such as fish or fruits and vegetables). For protein intake, the participants reflected that students were more likely to eat chicken rather than fish. If the menu served is chicken-based, the majority of the students will go to the dining hall to get their meals. One principal $(P-C)$ found chicken is still considered as students' first choice as he stated: "they prefer to eat only chicken, not vegetables," and teachers (T1-A, T2-A, T1-B) also supported: "most of the students dislike vegetables.. and lots of vegetable wastage, they prefer chicken more." In a study investigating factors that inhibit adolescents' fish consumption, Birch, Memery, Johns, and Musarskaya (2018) reported that adolescents' perceptions about the smell, fishbone, unpleasant cooking styles, and fish is non-familiar meals to be served at home are considered as barriers that prevent them from consuming fish. The adolescents further mentioned that the preparation of a fish-based menu without skin, bones, head, or tails need to be highlighted to gain adolescents' attractions to consume fish as their daily intake.

Other types of food students will love to eat something like processed food such as sausages, nuggets, and burgers. A teacher (T2-D) reported that: "the first thing they like chicken, then sausages or nuggets..let say if supper menu is burger they will like it so much." Principals $(P$ $D)$ also rose: "those fried food are students' favorite.. if we do not provide that type of food students won't eat, and we felt sorry to them.they demand and request, so they want their choice sold at the canteen." Another teacher (T1-A) explained that their biggest challenge related to students' preference was that students were much likely to eat food that tastes good than a healthier one. He notified: "nowadays students prefer food which tastes good rather than healthy." In line with our findings, it confirms that most adolescents overwhelmingly craved towards sweet, oily, and fatty foods and taste has a greater impact on their food selections and consumptions (Southerland, Dula, \& Slawson, 2019; Tiedje et al., 2014; Verstraeten et al., 2014). A teacher (T2-A) also reported that students who have money were spending to buy food from the canteen even if the canteen offers less healthy meals than what the dining hall was offering based on the policy. She said: "if they have money they will prefer to eat at the canteen because they can choose what they want to eat." Students' food preferences are also associated with monetary power, and the conception of "good food" rather than is "good for you" (Tiedje et al., 2014). This supports previous findings in Ecuadorian adolescents, where the availability of monetary power leads them to purchase poor nutritional quality foods at school and also gives them the freedom to choose what they love to eat (Verstraeten al., 2014). Moreover, fast-foods are known as convenience food, or something tasty or easy to eat (Elbel, Gyamfi, \& Kersh, 2011; Mohammadbeigi et al., 2018; Steyn, Labadarios, \& Nel, 2011).

\section{Students' Eating Style}

From the perception of participants, they believed the policy is hard to be followed substantially because of the students eating style factor. Most of the teachers (T1-A, T1-B, T1-C, T2-D) found that students' eating styles can be a challenge to inhibit the implementation of school healthy eating policy. The qualitative findings presented boarding school students were more likely to eat late at night, and they always tend to feel hungry frequently. For example, one teacher $(T 1-C)$ explained: "some students tend to eat at midnight..they always feel hungry." 


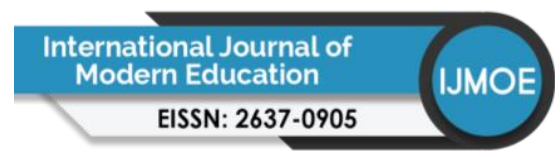

Volume 3 Issue 9 (June 2021) PP. 50-65 DOI: 10.35631/IJMOE.39005

He further added: "some students they already ate at the dining hall, then they feel hungry again and ate at the canteen, during midnight they eat again..I have done spot-check and I found there were students eating chicken chop around 2am-3am." By looking at the factors influencing eating behavior at late night, hunger is the most significant reasons explained by the participants which lead the students' inclination to eat at late night, and it is paralleled with a study done to assess night eating habits with a meal-time frequency between 10 p.m and 11 p.m among middle school students in Korea (Cho, Kim, Kim, \& Choi, 2014). Further, the authors reported the favorite menus for night eating mainly consisted of those with low nutritional values and high consumption of carbohydrates and fats. Hernandez, Kim, Kim, and Yoon (2016) further supported not only poor diet quality but late-night overeating among the Korean adolescents also showed a great increment in skipping breakfast meals. The tendency of having meals at late night by consuming high energy-dense food, overall causing weight gain (Watanabe et al., 2014).

This study found that meal skipping was prevalent among students in boarding schools, and the most frequent time that they missed take their meals is during breakfast and tea-time. However, some students also do miss their meals during lunch or dinner, and most of them are female students. Female students were more likely to skip eating or preferred to eat either lunch or dinner only. A teacher (T1-C) further explained that: "female students concern much about their weight, so they tend to eat less." The teachers (T1-A, T1-B, T1-C, T2-D) also further discussed the difference in eating styles between male and female students at their school. They recognized male students tend to eat more than the suggested serving size as compared to female students. A teacher (T1-C) reported: "male students tend to eat more rice..they eat more from serving size suggestions." Another teacher $(T 2-C)$ also notified the same thing: "there are cases where food is not enough for female students because male students eat more, especially during the weekends." The gender differences appeared to influence the frequency of consumption of food type. Male consume high energy intake, energy density, and percentage of energy from lipids as compared to females. Female students are more interested in dieting and bodyweight management control especially during the college years, thus they consume healthier dietary pattern such as fruits and vegetables because they have better motivation to adopt healthy eating and are better informed on nutritional value than male students (Leblanc, Begin, Corneau, Dodin, \& Lemieux, 2015; Lupi et al., 2015; Yahia, Brown, Rapley, \& Chung, 2016).

Life as students in the boarding school is tight with activities and very busy. Based on these qualitative findings, the most reason students skip their breakfast because of a tight schedule, wake up late in the morning, rush to classes, and only light meals were served during breakfast occasionally. The main factor associated with these reasons is the time constraint to eat breakfast before the class start at 7 a.m. A teacher (T1-C) commented: "students always skip breakfast because they are run out of time as classes start at 7 am." Similarly to local studies, breakfast was the main frequent mealtime that is mostly ignored by the adolescents (Hoque, Kamaluddin, Abdul Razak, Abdul Wahid, 2016; Rezali, Chin, \& Mohd Yusof, 2012) and it is also consistent with several other studies (AlBashtawy, 2015; Deshmukh-Taskar et al., 2010; Sun et al., 2013; Levitsky, \& Pacanowski, 2013). Previous studies have also indicated the possible explanations students always skip their breakfast because of time constraints, getting up late, dislike to eat in the morning, not feeling hungry, and unappealing meals (Ozdogan, Ozcelik, \& Surucuoglu, 2010; Jackson 2013; Sirichakwal, Janesiripanich, Kunapun, Senaprom, \& Purttipornthanee, 2018). 


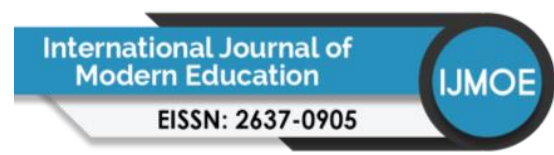

Volume 3 Issue 9 (June 2021) PP. 50-65 DOI: $10.35631 / \mathrm{IJMOE} .39005$

\section{Unchanged Menu Selections}

One of the barriers were described by the participants $(P-B, P-C, P-D)$ that were not supportive of policy implementation is the unrevised menu for an extended period. A principal $(P-E)$ perceived the development of the menu as good enough because it complements with a balance in nutrients, but she disagreed with the rotation of the menu which needs changes. She commented: "to me, the menus are good enough, but the rotation of menu choices need changes..there is a week only serve chicken..chicken and then the following week only fish and fish." The lack of menu choices being served in the dining hall causes the students to feel bored and less interested to eat at the dining hall as they have stayed in the dormitory from form 1 to form 5. Two teachers (T1-C, T2-D) expressed: "students stay here for five years, and they feel bored with the same menu for over the years..no changes in the menu." This is also supported by a teacher (T2-C) when she mentioned that: "the menus should have varieties because if no changes for a long time students are less interested to eat at the dining hall." According to Ishida (2018), the enactment of the school meal policy needs to be reviewed, and any amendment must be taken based on the current population's dietary eating pattern and healthrelated issues. Thus, the need to review and reform the menus for better improvements is imperative to facilitate the policy implementation and also to increase healthy meal intake among the students, specifically at the dining hall. In a word, lack of menu choices and cooking varieties, the same menu for a long period, unappealing menu rotation, and less concern on revising the menu are those barriers that may inhibit the effectiveness of implementing school healthy eating policy.

\section{Unhealthy Choices of Menu Canteen}

A significant challenge by most of the participants since they felt the availability of unhealthy choices at the canteen complies with students' preferences and thus presented difficulties in implementing the policy. Notably, the most preferred items among the students are processed food such as nuggets, sausages, and burgers. Those unhealthy selections are sold in the canteen because of their demands. Supposedly the canteen operators are not encouraged to sell those items every day but those "sell less" or "not for sale" items according to the policy were most favorite choices among the students. Two principals $(P-C, P-E)$ explained: "students will eat at the canteen during recess time, they like very much "nasi lemak", fried food like sausages, nuggets, fries and many more choices..if we refer to the policy the canteen operators cannot sell them every day but those foods are the ones students like so much." The canteen operators not only sell the unhealthy items, but the teachers also complained those items sold are low in quality grade. They evaluated that the unhealthy items are cheap, low quality, and similar to the ones sold in the night market. But the problem is the foods that were offered were up to the students' liking. Most of the school canteens did not provide many fruits and vegetable selections to be sold as part of their meals to the students. They only sell items that students prefer and make a profit from the items. Teachers (T1-B, T1-C, T1-D) described that: "fishballs, nuggets, and hotdogs sold in the canteen are low quality like the one sold at the night market..too many fast foods and no fruits sold, but those foods are students' favorites..not many vegetable selections." The school has the authority to prevent the canteen from selling those unhealthy items, but in a real situation, it is tough for the canteen operator to follow the rules. A principal further added: "we have the power to prohibit the unhealthy food at schools, but it is so hard to implement." One principal $(P-B)$ also explained most types of food sold in the canteen are lots of sweet items and no fiber at all. He clarified that: "menus sold in the canteen are unhealthy..lots of sweet food and no fruits are sold." A teacher (T2-B) added: "the selection of the menu in the canteen are low fiber.. if they sell fried rice no vegetables..they also 


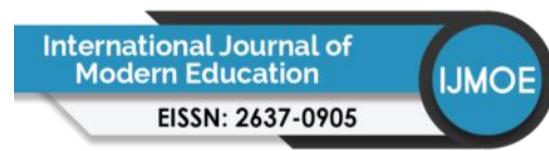

Volume 3 Issue 9 (June 2021) PP. 50-65 DOI: 10.35631/IJMOE.39005

sell drinks with colorings to the students and students tend to choose food high in carbohydrates, protein, fat but less fiber." Teachers (T1-A, T2-B, T1-C, T2-D) also further explained the students like to have their meals at the canteen because of many selections offer that meet their preferences. Students have options to choose what they want to eat at the canteen. The boredom of the menu offered at the dining hall causes them to get their food at the canteen. This has been emphasized by a teacher (T1-A), he found that: "students tend to eat at the canteen because of the selections of menus..let say for today, if they want fried rice they can have it at canteen..at the dining halls menus are fix based on the policy." The availability of unhealthier choices such as high-fat food and none or minimal choice of fibre selections was associated with poor healthy intake among the students (Muda et al., 2017). Furthermore, the sales of unhealthy items led to high sales volume and profit margins in the business of food operators (Choi, Frongillo, Blake, Thrasher, 2019). Thus, the healthy eating patterns were diminished by access to poorly regulated unhealthy choices available for purchase in the school canteen or cafeteria (Bevans et al., 2012; Masse et al., 2014; Rathi, Riddel, \& Worsley, 2018).

\section{Conclusion}

Although the sample size in this study cannot be generalized, we managed to capture the perspectives of participants known to have implemented the school healthy eating policy at the time of the study. Additionally, the same themes that emerged were repeated in all interviews. The study was undertaken in the Malaysian context, but we believe that these findings will be transferable to other countries and also might be relevant to different settings that adhere to the healthy eating policy in their operations. To facilitate school healthy eating policy implementation, several strategies, and the key to the improvement areas were recognized. The participants suggested a collaboration with the researchers and experts to develop school nutrition program intervention as a compulsory module to determine the right eating pattern and students' knowledge of nutrition. This can be done as part of a health program in school activities and get the involvement from school management and students to plan and lead activities. They further explained the current standard menu for boarding schools should be revised focusing on the calorie content, portion sizes, types of menus, method of cooking, new healthier recipes, and menu rotations. Currently, the development of the menu was created by expertise in the ministry such as a dietitian, but from this study participation from schools and students should be considered as part of the development of menu planning to accommodate the students' preferences in the real context. Encourage students and teachers to eat together so students can express their opinions about school meal presentation and meal quality. Supports from teachers concerning students' school meals need to be put as a priority matter. Participants also recommended limiting the time frame for students to get their food from the canteen during school meal hours. Mandated meal-time compulsory during breakfast, lunch, and dinner to encourage students to get their balance meals at the dining hall and do not allow students to purchase food at this time.

Framing nutrition as a core priority in a school setting needs co-operation from the school authorities to foster the creation of supportive nutrition environments for adolescents. This is not to suggest that school authorities the only player that has to play the major role in implementing the policy rather, those efforts must seek to understand and work inside the complexities of school systems. Various aspects need to be taken into accounts such as how decisions are made, how resources are allotted, how personnel duties are assigned, the autonomy of individual schools, the influence of teachers, and many others. More consistent 


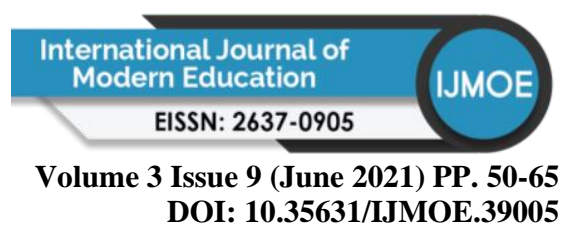

messaging and support from the multiple tiers of policy groups reinforce healthy school food practices through policy implementation.

\section{References}

Abdul Aziz, M. F., \& Devi, M. N. (2012). Nutritional status and eating practice among children aged 4-6 years old in selected urban and rural kindergarten in Selangor, Malaysia. Asian J.Clin.Nutr, 4, 116-131.

Abdul Majid, H., Ramli, L., Ying, S. P., Su, T. T., Jalaludin, M. Y., \& Abdul Mohsein, N. A. (2016). Dietary intake among adolescents in a middle-income country: An outcome from the Malaysian health and adolescents longitudinal research team study (the MyHeARTs study). PloS One, 11(5).

Agron, P., Berends, V., Ellis, K., \& Gonzalez, M. (2010). School wellness policies: Perceptions, barriers, and needs among school leaders and wellness advocates. Journal of School Health, 80(11), 527-535.

ALBashtawy, M. (2015). Overweight and obesity interventions and prevention strategies. Nursing Children and Young People, 27(7), 16-21.

Al-Sadat, N., Majid, H. A., Sim, P. Y., Su, T. T., Dahlui, M., Abu Bakar, M. F., . .MyHeART study group. (2016). Vitamin D deficiency in Malaysian adolescents aged 13 years: Findings from the Malaysian health and adolescents longitudinal research team study (MyHeARTs). BMJ Open, 6(8).

Bass, L. R. (2014). Boarding schools and capital benefits: Implications for urban school reform. The Journal of Educational Research, 107(1), 16-35.

Beets, M. W., Tilley, F., Kyryliuk, R., Weaver, R. G., Moore, J. B., \& Turner-McGrievy, G. (2014). Children select unhealthy choices when given a choice among snack offerings. Journal of the Academy of Nutrition and Dietetics, 114(9), 1440-1446.

Birch, D., Memery, J., Johns, N., \& Musarskaya, M. (2018). Stimulating UK adolescents' seafood consumption. Journal of International Food \& Agribusiness Marketing, 30(1), 61-69.

Brown, T., \& Summerbell, C. (2009). Systematic review of school-based interventions that focus on changing dietary intake and physical activity levels to prevent childhood obesity: An update to the obesity guidance produced by the national institute for health and clinical excellence. Obesity Reviews, 10(1), 110-141.

Buluku, E. (2012) An Assessment of the Adequacy of School Meals in Meeting the Nutritional Requirements of Girls in Boarding Secondary Schools in Nairobi; Kenyatta University: Nairobi, Kenya. Available online: http://irlibrary.ku.ac.ke/handle/123456789/2516.

Cho, Y., Kim, M., Kim, M., \& Choi, M. (2014). Night eating habits of middle school students in Gyeonggi. Journal of the Korean Society of Food Science and Nutrition, 43(2), 300308.

Choi, J. H., \& Rajagopal, L. (2013). Food allergy knowledge, attitudes, practices, and training of foodservice workers at a university foodservice operation in the Midwestern United States. Food Control, 31(2), 474-481.

Cohen, J. F., Richardson, S., \& Rimm, E. B. (2019). Impact of the updated USDA school meal standards, chef-enhanced meals, and the removal of flavored milk on school meal selection and consumption. Journal of the Academy of Nutrition and Dietetics, 119(9), 1511-1515.

Cygan, H., Tribbia, C., \& Tully, J. (2019). School health policy implementation: Facilitators and challenges. The Journal of School Nursing, 36(5), 330-338. 


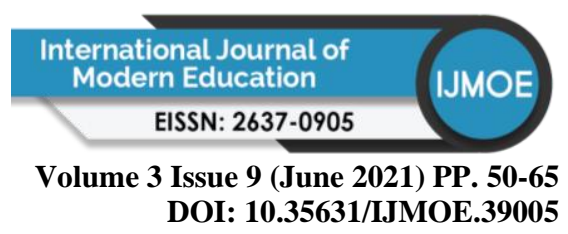

Deshmukh-Taskar, P. R., Nicklas, T. A., O'Neil, C. E., Keast, D. R., Radcliffe, J. D., \& Cho, S. (2010). The relationship of breakfast skipping and type of breakfast consumption with nutrient intake and weight status in children and adolescents: The national health and nutrition examination survey 1999-2006. Journal of the American Dietetic Association, 110(6), 869-878.

Dobbins, M., Husson, H., DeCorby, K., \& La Rocca, R. L. (2013). School-based physical activity programs for promoting physical activity and fitness in children and adolescents aged 6 to 18. Cochrane Database of Systematic Reviews, (2), 2-8.

Elbel, B., Gyamfi, J., \& Kersh, R. (2011). Child and adolescent fast-food choice and the influence of calorie labeling: A natural experiment. International Journal of Obesity, 35(4), 493.

Hernandez, E., Kim, M., Kim, W. G., \& Yoon, J. (2016). Nutritional aspects of night eating and its association with weight status among Korean adolescents. Nutrition Research and Practice, 10(4), 448-455.

Hoxie-Setterstrom G, Hoglund B. School wellness policies: opportunities for change. J Sch Nurs. 2011; 27(5):330-339.

Food Agriculture Organization (2019). Nutrition Guidelines and Standards for School Meals: A Report from 33 Low and Middle-Income Countries; Food and Agriculture Organization of the United Nations: Rome, Italy, pp. 10-11. Available online: http://www.fao.org/3/CA2773EN/ca2773en.pdf

Fritts, J. R., Fort, C., Corr, A. Q., Liang, Q., Alla, L., Cravener, T., . . Keller, K. L. (2018). Herbs and spices increase liking and preference for vegetables among rural high school students. Food Quality and Preference, 68, 125-134.

Fryar, C. D., Carroll, M. D., \& Ogden, C. L. (2018). Prevalence of overweight, obesity, and severe obesity among children and adolescents aged 2-19 years: United States, 19631965 through 2015-2016.

Gase, L. N., McCarthy, W. J., Robles, B., \& Kuo, T. (2014). Student receptivity to new school meal offerings: Assessing fruit and vegetable waste among middle school students in the Los Angeles unified school district. Preventive Medicine, 67, S28-S33.

Handforth, K. M., Gilboy, M. B., Harris, J., \& Melia, N. (2016). Fruit and vegetable plate waste among students in a suburban school district participating in the national school lunch program. J Child Nutr Manag, 40(1).

Helble, M., \& Francisco, K. (2017). The imminent obesity crisis in Asia and the Pacific: First cost estimates.

Hirschman, J., \& Chriqui, J. F. (2013). School food and nutrition policy, monitoring and evaluation in the USA. Public Health Nutrition, 16(6), 982-988.

Hoque, K. E., Kamaluddin, M. A., Razak, A. Z. A., \& Wahid, A. A. A. (2016). Building healthy eating habits in childhood: A study of the attitudes, knowledge and dietary habits of schoolchildren in Malaysia. Peerj, 4, 2651-2655.

Ishida, H. (2018). The history, current status, and future directions of the school lunch program in Japan. The Japanese Journal of Nutrition and Dietetics, 76(Supplement), S2-S11.

Koo, H., Kaur, S., Chan, K., Soh, W., Ang, Y., Chow, W., . . Yap, M. (2020). Whole-grain intake and its inverse relationships with fatty acids intake among multiethnic Malaysian schoolchildren. Journal of Human Nutrition and Dietetics, 33(5), 670-677.

Jackson, L. W. (2013). The most important meal of the day: Why children skip breakfast and what can be done about it. Pediatric Annals, 42(9), 194-197.

Khalidi, J.R., \& Gen, T. Z. (2020). Understanding school feeding in Malaysia. Khazanah Research Insitute. Retrieved from 


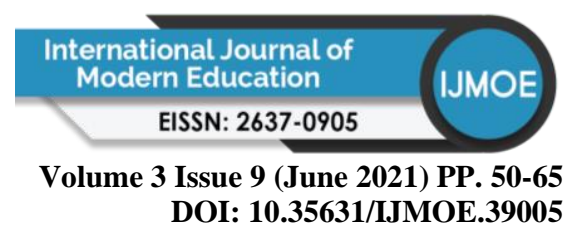

http://www.krinstitute.org/assets/contentMS/img/template/editor/20200207_Understa nding\%20School\%20Feeding\%20in\%20Malaysia.pdf.

Krolner, R., Rasmussen, M., Brug, J., Klepp, K., Wind, M., \& Due, P. (2011). Determinants of fruit and vegetable consumption among children and adolescents: A review of the literature. part II: Qualitative studies. International Journal of Behavioral Nutrition and Physical Activity, 8(1), 112.

Leblanc, V., Bégin, C., Corneau, L., Dodin, S., \& Lemieux, S. (2015). Gender differences in dietary intakes: What is the contribution of motivational variables? Journal of Human Nutrition and Dietetics, 28(1), 37-46.

Levitsky, D. A., \& Pacanowski, C. R. (2013). Effect of skipping breakfast on subsequent energy intake. Physiology \& Behavior, 119, 9-16.

Llewellyn, A., Simmonds, M., Owen, C. G., \& Woolacott, N. (2016). Childhood obesity as a predictor of morbidity in adulthood: A systematic review and meta-analysis. Obesity Reviews, 17(1), 56-67.

Maietta, O. W., \& Gorgitano, M. T. (2016). School meals and pupil satisfaction evidence from Italian primary schools. Food Policy, 62, 41-55.

Mâsse, L. C., de Niet-Fitzgerald, J. E., Watts, A. W., Naylor, P., \& Saewyc, E. M. (2014). Associations between the school food environment, student consumption and body mass index of Canadian adolescents. International Journal of Behavioral Nutrition and Physical Activity, 11(1), 29.

Mensah, C., \& Appietu, M. E. (2019). Examining boarding school foodservice satisfaction and patronage of sources of meals. Journal of Culinary Science \& Technology, 1-20.

Micha, R., Karageorgou, D., Bakogianni, I., Trichia, E., Whitsel, L. P., Story, M. Mozaffarian, D. (2018). Effectiveness of school food environment policies on children's dietary behaviors: A systematic review and meta-analysis. PLoS One, 13(3), 115-123.

Ministry of Education (2010a). Pengurusan pemakanan asrama sekolah berasrama penuh. Cyberjaya: Kementerian Pelajaran Malaysia.

Ministry of Education (2007). Menu makanan asrama Kementerian Pelajaran Malaysia (sekolah menengah). Putrajaya: Kementerian Pelajaran Malaysia.

Ministry of Health, National Coordinating Committee on Food and Nutrition (2016). National plan of action for nutrition of Malaysia (2016-2025). Retrieved from http://nutrition.moh.gov.my/wp-content/uploads/2016/12/NPANM_III.pdf.

Mohammadbeigi, A., Asgarian, A., Moshir, E., Heidari, H., Afrashteh, S., Khazaei, S., \& Ansari, H. (2018). Fast-food consumption and overweight/obesity prevalence in students and its association with general and abdominal obesity. Journal of Preventive Medicine and Hygiene, 59(3), 236-245.

Muda, W. M. W., Jamil, N. I. N., Hanafi, N. N. N., \& Abdul Rahman, R. (2017). How healthy is competitive food served at primary school canteen in Malaysia. International Medical Journal, 24(1), 44-47.

Ozdogan, Y., Ozcelik, A. O., \& Surucuoglu, M. S. (2010). The breakfast habits of female university students. Pakistan Journal of Nutrition, 9(9), 882-886.

Parker, E. A., Feinberg, T. M., Bowden, B., Bahr-Robertson, M., Keller, K. L., Berman, B. M., \& D'Adamo, C. R. (2018). Spices and herbs increased vegetable palatability among underserved urban adolescents. Health Behavior and Policy Review, 5(6), 76-89.

Rathi, N., Riddell, L., \& Worsley, A. (2018). Barriers to nutrition promotion in private secondary schools in Kolkata, India: Perspectives of parents and teachers. International Journal of Environmental Research and Public Health, 15(6), 1139. 


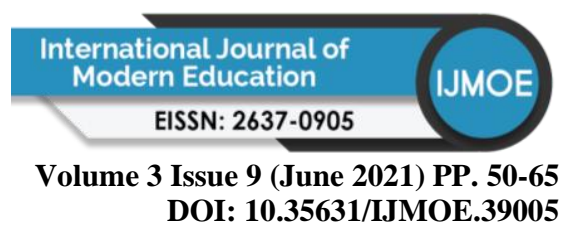

Reinehr, T. (2018). Long-term effects of adolescent obesity: Time to act. Nature Reviews Endocrinology, 14(3), 183-190.

Rezali, F. W., Chin, Y. S., Yusof, M., \& Nisak, B. (2012). Obesity-related behaviors of Malaysian adolescents: A sample from Kajang district of Selangor state. Nutrition Research and Practice, 6(5), 458-465.

Rosmawati, N. N., Manan, W. W., Izani, N. N., Nurain, N. N., \& Razlina, A. (2017). Impact of food nutrition intervention on food handlers' knowledge and competitive food serving: A randomized controlled trial. International Food Research Journal, 24(3), 1046-1055.

Serrem, K., Dunay, A., Serrem, C., Atubukha, B., Oláh, J., \& Illés, C. B. (2020). Paucity of nutrition guidelines and nutrient quality of meals served to Kenyan boarding high school students. Sustainability, 12(8), 3463-3475.

Schwartz, M. B., Henderson, K. E., Falbe, J., Novak, S. A., Wharton, C. M., Long, M. W., .. . Fiore, S. S. (2012). Strength and comprehensiveness of district school wellness policies predict policy implementation at the school level. Journal of School Health, 82(6), 262267.

Schwartz, M. B., Henderson, K. E., Read, M., Danna, N., \& Ickovics, J. R. (2015). New school meal regulations increase fruit consumption and do not increase total plate waste. Childhood Obesity, 11(3), 242-247.

Schwartz, M. B., Henderson, K. E., Falbe, J., Novak, S. A., Wharton, C. M., Long, M. W., ... Fiore, S. S. (2012). Strength and comprehensiveness of district school wellness policies predict policy implementation at the school level. Journal of School Health, 82(6), 262267.

Sieberg, R. (2018). Exploring the relationship between quality of written school wellness policy and the degree of wellness policy implementation in elementary schools. (Unpublished master thesis). South Dakota State University, United States.

Snelling, A., Belson, S. I., Watts, E., Malloy, E., Van Dyke, H., George, S., . . Katz, N. B. (2017). Measuring the implementation of a school wellness policy. Journal of School Health, 87(10), 760-768.

Southerland, J. L., Dula, T. M., \& Slawson, D. L. (2019). Barriers to healthy eating among high school youth in rural southern Appalachia. Journal of Appalachian Health, 1(2), 31-40.

Steyn, N. P., Labadarios, D., \& Nel, J. H. (2011). Factors which influence the consumption of street foods and fast foods in South Africa-a national survey. Nutrition Journal, 10(1), 104-115.

Sun, H., Ma, Y., Han, D., Pan, C., \& Xu, Y. (2014). Prevalence and trends in obesity among China's children a nd a dolescents, 1985-2010. PloS One, 9(8).

Tan, Z., Rifan, N., Khalid, K., Musa, M., \& Anuar, J. (2015). Foodborne illness risk factors in institutional foodservice: Utilizing temperature control as a preventive measure. Journal of Applied Environmental and Biological Sciences, 5(6), 33-39.

Tiedje, K., Wieland, M. L., Meiers, S. J., Mohamed, A. A., Formea, C. M., Ridgeway, J. L., . .. Nigon, J. A. (2014). A focus group study of healthy eating knowledge, practices, and barriers among adult and adolescent immigrants and refugees in the United States. International Journal of Behavioral Nutrition and Physical Activity, 11(1), 63.

Valaitis, R. (2015). Implementation of Ontario's School Food and Beverage Policy (P/PM150) in Peel Region: A Qualitative Evaluation. (Unpublished doctoral dissertation). University of Waterloo, Canada. 
Volume 3 Issue 9 (June 2021) PP. 50-65 DOI: $10.35631 / \mathrm{IJMOE} .39005$

Verstraeten, R., Van Royen, K., Ochoa-Avilés, A., Penafiel, D., Holdsworth, M., Donoso, S., . . . Kolsteren, P. (2014). A conceptual framework for healthy eating behavior in Ecuadorian adolescents: A qualitative study. PloS One, 9(1).

Wansink, B., Just, D. R., Hanks, A. S., \& Smith, L. E. (2013). Pre-sliced fruit in school cafeterias: Children's selection and intake. American Journal of Preventive Medicine, 44(5), 477-480.

Watanabe, Y., Saito, I., Henmi, I., Yoshimura, K., Maruyama, H., Yamauchi, K., . . Kishida, T. (2014). Skipping breakfast is correlated with obesity. Journal of Rural Medicine, 2887-2898.

Weaver-Hightower, M. B. (2011). Why education researchers should take school food seriously. Educational Researcher, 40(1), 15-21.

World Health Organization (2014). Global strategy on diet, physical activity and health: Childhood overweight and obesity. Retrieved from http://www.who.int/dietphysicalactivity/childhood/en.

Yahia, N., Brown, C. A., Rapley, M., \& Chung, M. (2016). Level of nutrition knowledge and its association with fat consumption among college students. BMC Public Health, 16(1), 1047. 